\title{
MELILOTUS WOLGICA POIR. IN LAM. (FABACEAE) IN EURASIA: DISTRIBUTION AND HABITATS
}

\author{
Julian Chmiel, SŁawomir Mielczarek
}

\begin{abstract}
J. Chmiel, Department of Plant Taxonomy, Faculty of Biology, Adam Mickiewicz University, Umultowska 89, 61-614 Poznań, Poland, e-mail: chmielju@amu.edu.pl

S. Mielczarek, Dworcowa 11/17, 62-510 Konin, Poland, e-mail: slawomirm65@gmail.com
\end{abstract}

(Received: July 20, 2016. Accepted: September 12, 2016)

\begin{abstract}
AвSTRACт. The work presents information about the range, occurrence conditions, geographical and historical status and dynamic tendencies of Melilotus wolgica in Eurasia and Poland. In Poland, the species was noted for the first time in Szczecin at the end of $19^{\text {th }}$ century. Later, it was observed in the anthropogenic localities in the Opole Province, Kraków and Warszawa. In Wielkopolska, M. wolgica was observed for the first time in 2012, south of Gosławice (Konin district), where a large population was found on the embankment of a coal ash storage reservoir of the Konin Power Plant in the former brown coal mine area.
\end{abstract}

KeY WORDS: Melilotus wolgica, geographical range, geographical and historical status, occurrence conditions, Eurasia, Poland, Wielkopolska

\section{INTRODUCTION}

In Europe, the genus Melilotus Miller (Fabaceae) is represented by 16 species (HANSEN 1968). In Poland, eight species were noted so far. Four of them: Melilotus alba Medik., M. altissima Thuill., M. dentata (Waldst. \& Kit.) Pers. and M. officinalis (L.) Pall. are considered native species (MireK et al. 2002).

Melilotus wolgica Poir. in Lam. is a Pontic species. Its natural range comprises eastern Ukraine, southern part of European Russia, up to western part of Kazakhstan. It rarely occurs in the northern part of Central and Western Europe as an adventive species. In Poland, it was noted so far in 10 localities (TRZCiŃSKA-TACIK 1967) and regarded as ephemerophyte (Rostański \& Sowa 1986-1987) or kenophyte (TOKARSKA-GUZIK 2005).

The main aim of this article was to characterise the occurrence conditions and size of Melilotus wolgica population in the locality Gosławice near Konin, as well as to try to make a preliminary diagnosis of the studied population stability. Also, the current state of knowledge about the environmental conditions, ways of spread, dynamic tendencies and distribution of Melilotus wolgica in Eurasia and Poland was presented.

\section{METHODS}

In the years 2010-2012, the intensive floristic investigations were conducted using field mapping technique. They covered all types of habitats, including anthropogenic, contained within $1-\mathrm{km}$ grid squares made according to the ATPOL system (ZAJĄC 1978). The basis of documentation of floristic relationships were floristic and ecological relevés. In cases justified by the need of defining plant communities, phytosociological relevés were made according to the Braun-Blanquet method (PAwŁowski 1977). Precise location of patches with $M$. wolgica was determined by GPS using the WGS 84 datum. The nomenclature of taxa (genera and species) was adopted after MireK et al. (2002), while for syntaxa after Matuszkiewicz (2001).

The collected specimens of $M$. wolgica were deposited in the Herbarium of Adam Mickiewicz University in Poznań (POZ).

\section{RESULTS}

Due to morphological similarity, Melilotus wolgica can be confused with M. alba. However, in M. wolgica, white flowers are slightly smaller and hang from a much longer pedicel than in $M$. alba (Table 1, Figs $1-3)$. 
Table 1. Comparison of diagnostic features of Melilotus wolgica and M. alba

\begin{tabular}{lll}
\hline \multicolumn{1}{c}{ Diagnostic feature } & \multicolumn{1}{c}{ Melilotus wolgica Poir. in Lam. } & \multicolumn{1}{c}{ Melilotus alba Medik. } \\
\hline Flower length $(\mathrm{mm})$ & $3-3.5$ & $4-5$ \\
Pedicel length $(\mathrm{mm})$ & $3-4$ (pliable, drooping) & $1-1,5$ (stiff, erect) \\
Pod length (mm) & $4.5-5$ & $3-3.5$ \\
Pod colour & yellow-brown & blackish \\
\hline
\end{tabular}

According to Bobrov (1939) and Dzyubenko \& DzyUBEnKo (2004), the compact range of $M$. wolgica comprises eastern Europe and western part of Asia: from the Azov Sea in the west to the upper and middle Irtysh river basin. In the southern part of the range, along the Volga River valley, it reaches the Caspian Sea (Fig. 4). Melilotus wolgica is a native species in the eastern Ukraine, south-west Russia and western part of Kazakhstan. Within its natural range, it grows in steppes (also saline), on gravel/sand river cliffs, in wet and saline grasslands, on fallows, baulks and even in crop fields as a segetal weed.

In central and western Europe, the species was sporadically noted at the end of the $19^{\text {th }}$ century (WitTe 1909, Höck 1910). The first records of the occurrence of M. wolgica in this part of Europe come from 1891 (Germany: Mannheim; НӧcK 1910) and 1890 (Sveden: Nacka-Stockholm; ArONSSON 1994) (App. 1).
In Poland, M. wolgica was found only in anthropogenic localities, especially, in the railway areas. For the first time, it was observed in Szczecin at the end of the $19^{\text {th }}$ century (leg. Moelendorf 1889; WITTE 1909: obs. in 1885). Later, it was noted in the Opole region (MichalaK 1971, 1976), as well as in the vicinity of Kraków and Medyka Rozrządowa (TRzciŃsKA-TACIK 1967), and in Warszawa (SUDNIK-WójciKowsKa 1987) (App. 2, Fig. 5A).

In Wielkopolska, M. wolgica was observed for the first time in 2012, about $1 \mathrm{~km}$ south of Gosławice, near Konin. This area is dominated by anthropogenic landforms, connected with the former exploitation of brown coal. The substratum consists of mixed geological deposits. The developing local flora and vegetation include mainly adventive and xenospontaneous elements (BALCERKIEWICZ \& PAWLAK 1990).

A post-mining excavation (185.1 ha in area), located in the northern part of the former brown

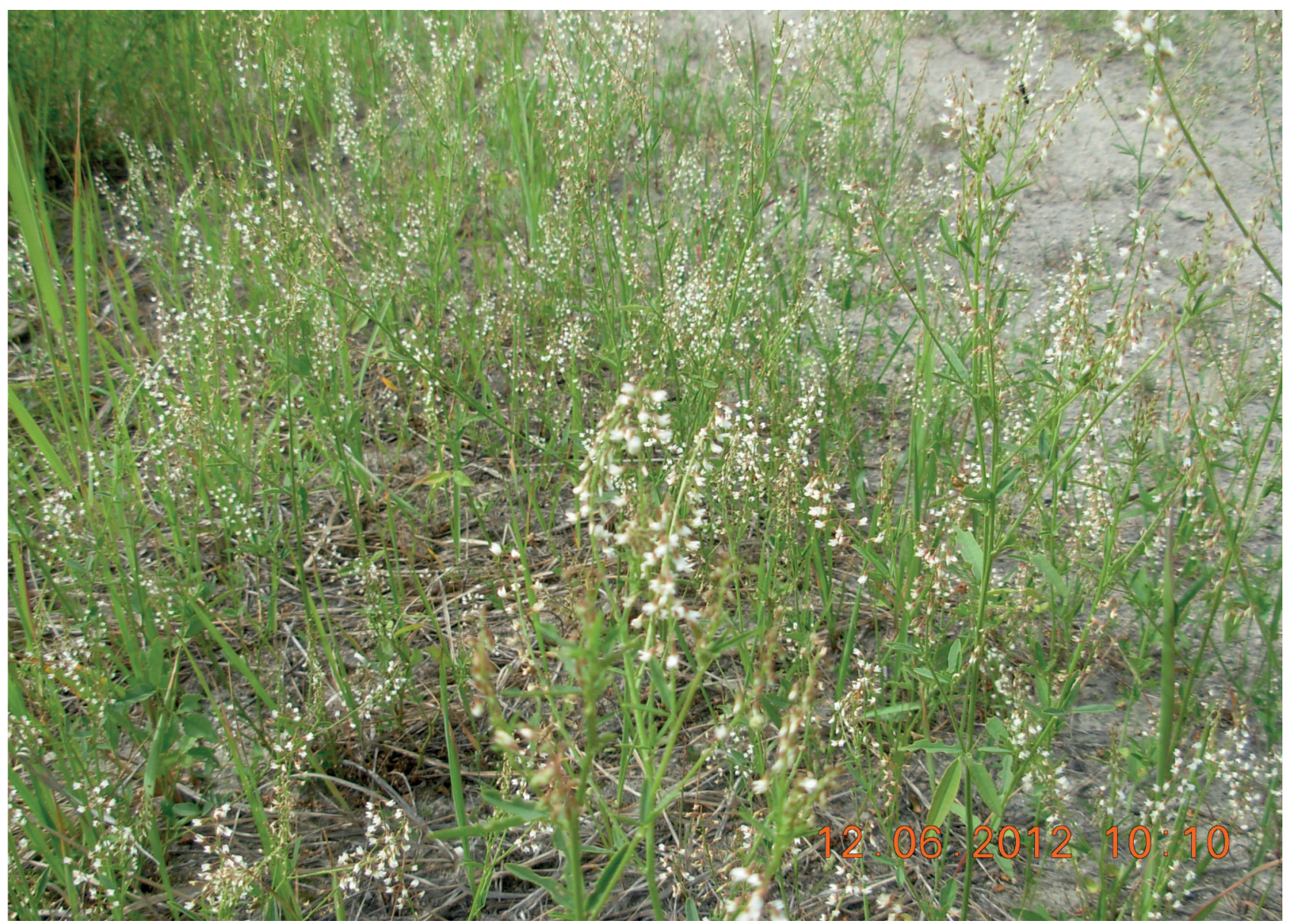

Fig. 1. Fragment of Melilotus wolgica population on the top of embankment in the vicinity of Gosławice (phot. J. CHMIEL, 12.06.2012) 


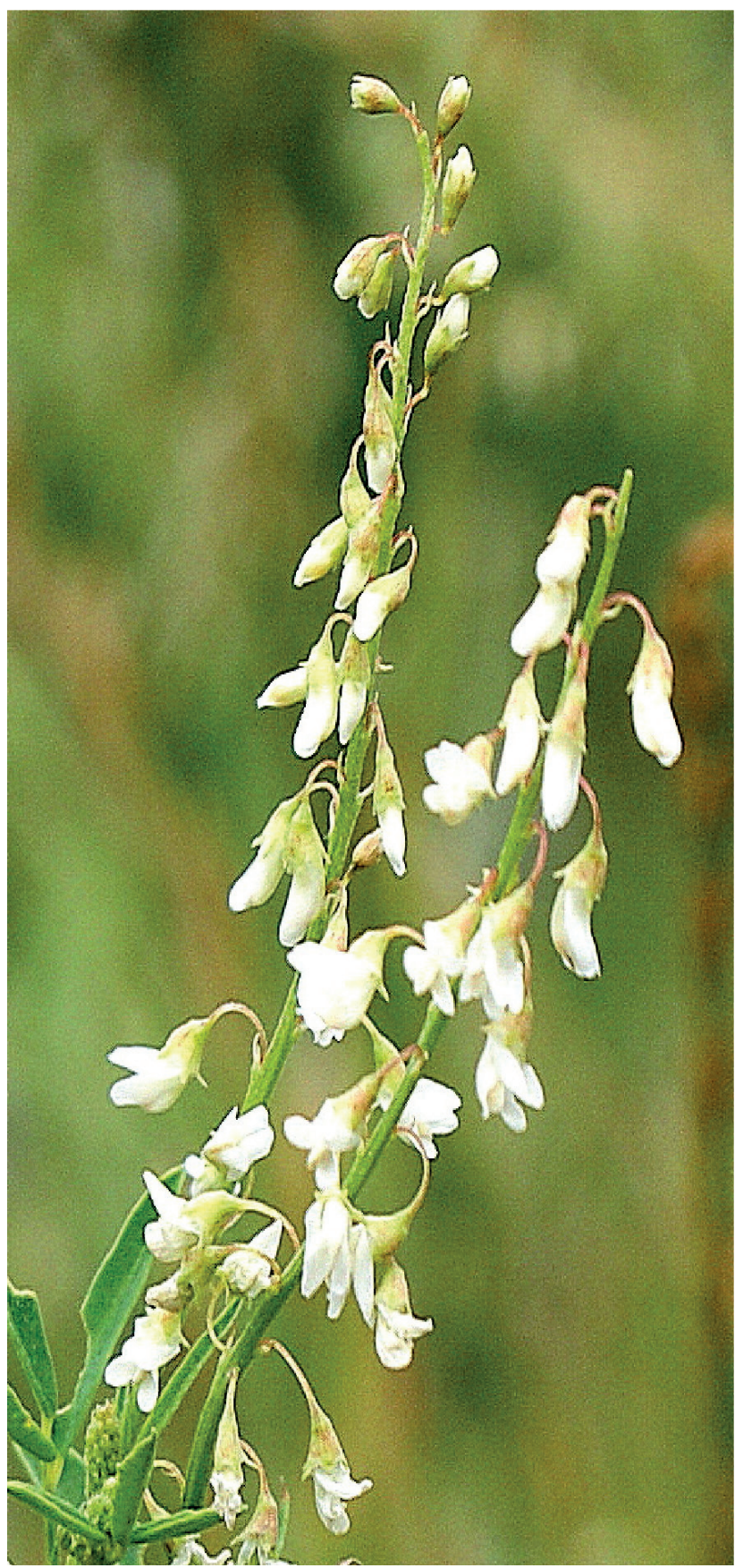

Fig. 2. Inflorescence of Melilotus wolgica (phot. S. MielczAREK, 27.06.2013)

coal mine in Gosławice, has been used as a coal ash storage site since 1977. Furnace waste in the form of semi-liquid ash and gravel mixture, as well as waste from the desulphurization of exhaust gases are transported via the pipeline system. According to KASIŃSKI (2005), sedimentary ashes are highly alkaline $(\mathrm{pH} \sim 12.0)$. In the southern part of the ash storage reservoir, a small, lifeless "lazure" lake is situated. No organic, nitrate, nitrite and phosphate compounds were found in the sediments.

In the eastern part of this reservoir, $M$. wolgica grows among other ruderal species in two vegetation patches covering $290 \mathrm{~m}^{2}$ in total:
Table 2. Plant community with Melilotus wolgica Poir. in Lam.

\begin{tabular}{|c|c|c|}
\hline No. of relevé & 1 & 2 \\
\hline Date & 16.06 .2012 & 16.06 .2012 \\
\hline Altitude a.s.1. (m) & 100 & 100 \\
\hline Latitude N & $52^{\circ} 16^{\prime} 38.9^{\prime \prime}$ & $18^{\circ} 15^{\prime} 47.8^{\prime \prime}$ \\
\hline Longitude $\mathrm{E}$ & $52^{\circ} 16^{\prime} 43.0^{\prime \prime}$ & $18^{\circ} 15^{\prime} 41.6^{\prime \prime}$ \\
\hline Area of the relevé & 10 & 25 \\
\hline Cover of herb layer (\%) & 70 & 40 \\
\hline Number of species in relevé & 21 & 10 \\
\hline Melilotus wolgica & + & 3.3 \\
\hline Ch. Ass. Melilotetum albo-officinalis & & \\
\hline Melilotus alba & + & $\mathrm{r}$ \\
\hline Melilotus officinalis & $\mathrm{r}$ & $\mathrm{r}$ \\
\hline Ch. Ass. Dauco-Picridetum hieracioidis & & \\
\hline Daucus carota & & + \\
\hline Pastinaca sativa & $\mathrm{r}$ & \\
\hline Ch. Ass. Tanaceto-Artemisietum & & \\
\hline Tanacetum vulgare & 2.2 & \\
\hline $\begin{array}{l}\text { Ch. Ass. Potentillo argenteae-Arte- } \\
\text { misietum absinthii }\end{array}$ & & \\
\hline Potentilla argentea & $\mathrm{r}$ & \\
\hline Ch. O. Onopordetalia acanthii & & \\
\hline Medicago lupulina & $\mathrm{r}$ & $\mathrm{r}$ \\
\hline Oenothera depressa & $\mathrm{r}$ & \\
\hline Artemisia campestris & & $\mathrm{r}$ \\
\hline Ch. Cl. Artemisietea vulgaris & & \\
\hline Artemisia vulgaris & 1.1 & \\
\hline Elymus repens & $\mathrm{r}$ & \\
\hline Hypericum perforatum & $\mathrm{r}$ & \\
\hline Ch. Cl. Stellarietea mediae & & \\
\hline Vicia tetrasperma & $\mathrm{r}$ & \\
\hline Vicia angustifolia & $\mathrm{r}$ & \\
\hline Others & & \\
\hline Calamagrostis epigejos & 3.3 & 3.3 \\
\hline Poa compressa & 1.1 & \\
\hline Medicago sativa & + & + \\
\hline Phalaris arundinacea & + & \\
\hline Festuca arundinacea & + & \\
\hline Trifolium repens & + & \\
\hline Solidago gigantea & + & \\
\hline Potentilla reptans & $\mathrm{r}$ & \\
\hline Puccinellia distans & & + \\
\hline Poa pratensis & & $\mathrm{r}$ \\
\hline
\end{tabular}

- population 1 comprises 36 individuals which occupy an area of about $60 \mathrm{~m}^{2}$ along an access dirt road to the top of embankment,

- population 2 consists of about 500 individuals growing on the top of embankment (build of mixed clay and loam) and covering an area of about $230 \mathrm{~m}^{2}$ (Fig. 5B, C).

Patches with $M$. wolgica are similar to phytocoenoses of the Melilotetum albo-officinalis association. The common species for both types of phytocoenoses are: Artemisia campestris, Melilotus alba, M. officinalis, Medicago sativa and M. lupulina. The dominant species is Calamagrostis epigejos. 


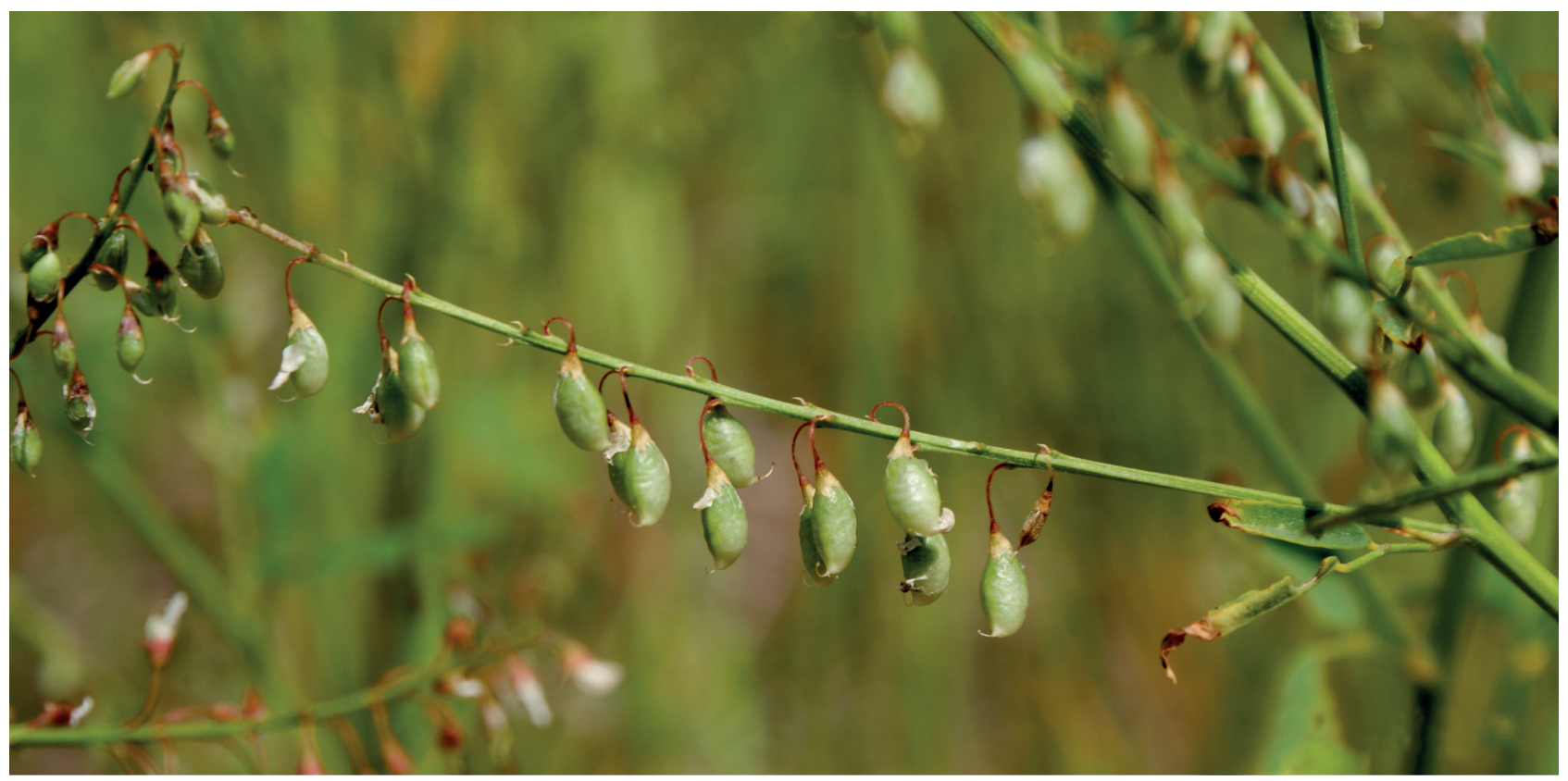

Fig. 3. Fruit of Melilotus wolgica (phot. S. MielczArek, 27.06.2013)

In 2012, the abundant flowering and fruiting and spontaneous seeding of $M$. wolgica was noted in the locality Gosławice. These findings indicate that, possibly, the studied species can be a stable element of flora of post-mining areas near Konin. However, to confirm this thesis, further observations are required.

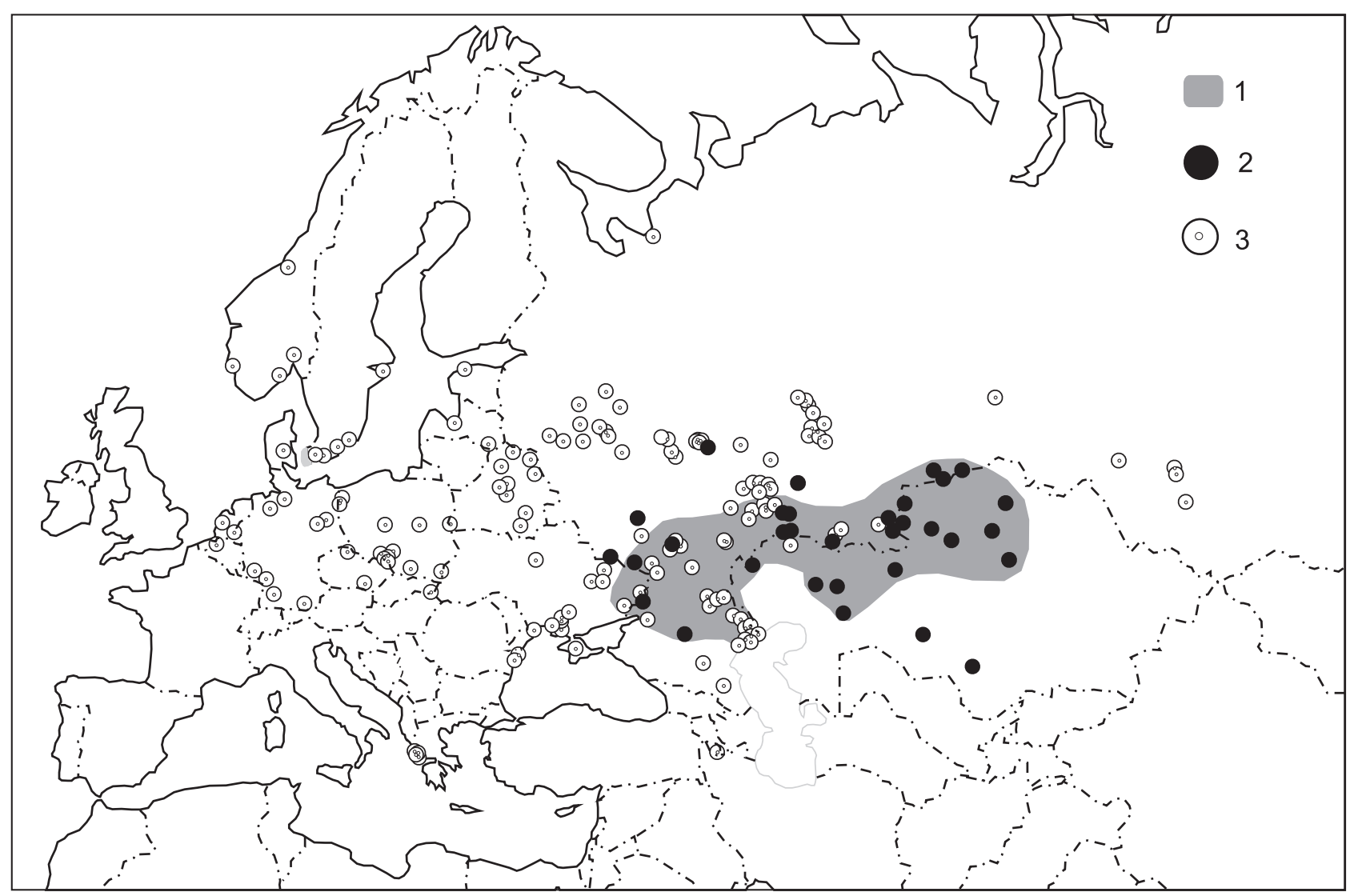

Fig. 4. Distribution of Melilotus wolgica in Eurasia: 1 - natural range (DzYUBENKO \& DzYUBENKo 2004; updated and modified), 2 - localities in natural habitats, 3 - localities in anthropogenic habitats 


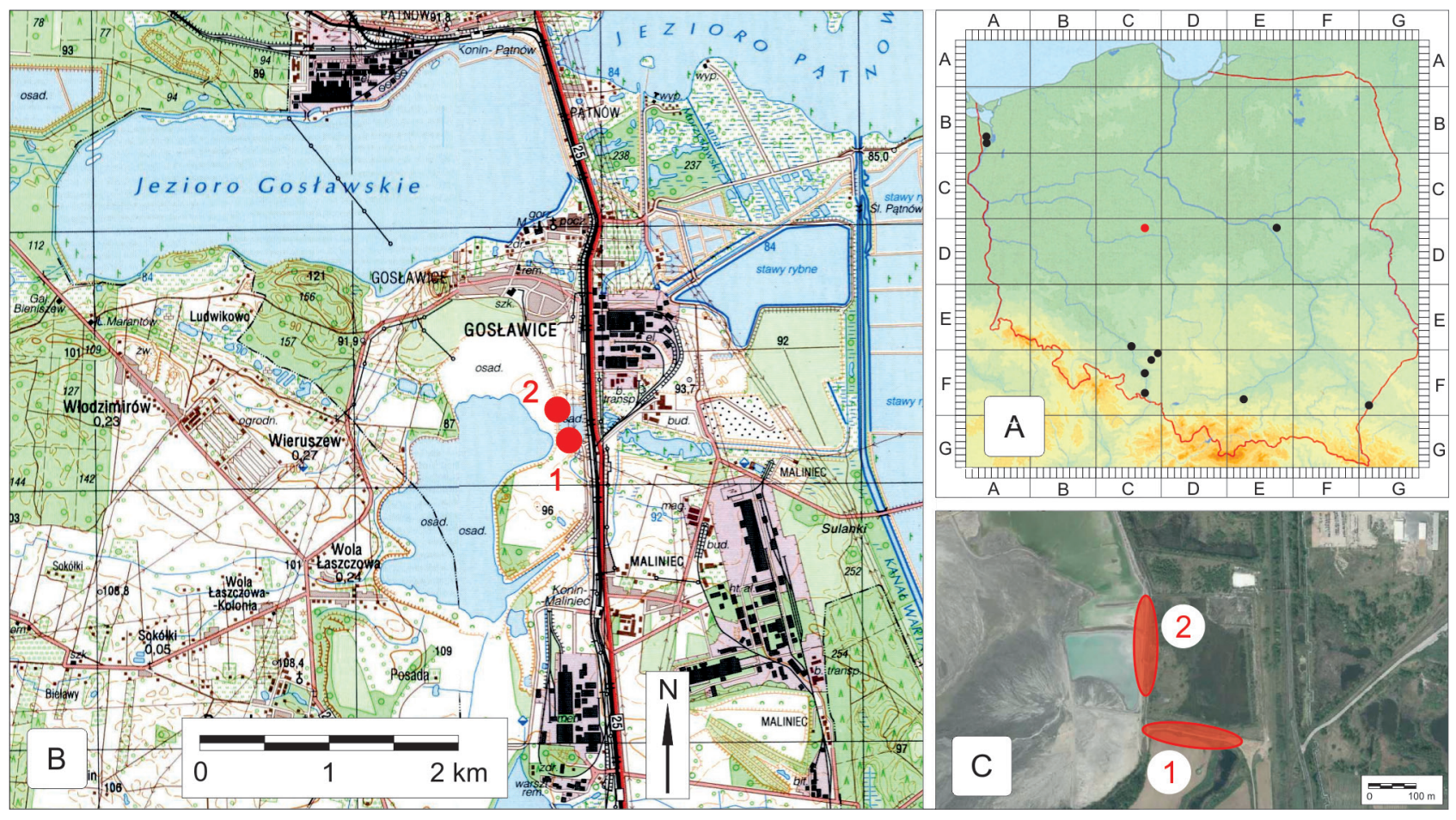

Fig. 5. Distribution of localities of Melilotus wolgica in Poland; after ZAJĄC \& ZAJĄC (2001), supplemented: red colour denotes the locality in Gosławice near Konin (A);

Locality of M. wolgica in Gosławice near Konin (1, 2 - locations of phytosociological relevés presented in Table 2): situational plan (B), precise location of the population (C)

\section{DISCUSSION}

Melilotus wolgica in natural habitats was recognised as a taxon that requires protection (NAUMENKO 2012, Naumenko et al. 2011). In Russia, this species and its habitats are protected within the following nature reserves: Galischya Gora, Rostovsky, Khopyorsky and Arkaim (TAlovina 2011). Probably, the main factor threatening natural habitats of $M$. wolgica was conversion of steppes into agricultural fields. As a consequence, the species, within its natural range of occurrence, was frequently found in field crops and at their margins (TRZCIŃSKA-TACIK 1967).

Geographic expansion of the species proceeds distinctly in a north-west direction. Essential for its migration are communication routes: roads and railway lines. The species dispersion is not gradual and regular in time and space. Numerous observations from Western Europe show that M. wolgica appears erratically, in sites considerably distant from the previous localities. In the Netherlands, Belgium, Germany, Denmark, Norway and Sweden, it was noted almost exclusively in port towns, where it was brought along with imported goods. Diaspores of M. wolgica, which were transported with cereals, spread ephemerically in the vicinity of mills, e.g., in Nacka near Stockholm (Aronsson 1994). Also, Baranova \& Puzyrev (2012), who noted the species in cereal and vegetable collecting centers, indicate the possibility of the species spread with agricultural products.
All occurrences of the species observed so far in Western Europe and Scandinavia were of ephemeral character and depended on allochtonic transport of diaspores to ruderal habitats. Effectiveness of spontaneous spread of diaspores was very small due to unfavorable marine climate conditions. Melilotus wolgica, which was recorded in this part of Europe over 100 years ago, did not obtain there the status of a naturalized species. Also, in Central Europe, the species is regarded as mostly ephemeral (GojDičoví et al. 2000, PYšEK et al. 2002).

In Eastern Europe, it is a relatively frequent and permanent element of ruderal habitat flora in the urban areas and along roads and railway tracks. However, it is not considered an expansive species (OstAPKO et al. 2009).

According to ToKarsKa-GuziK (2005), M. wolgica, within the present borders of Poland, was recorded for the first time in Szczecin in 1937 (Holzfuss 1937). However, the former German and Swedish sources indicate that this species has been observed in Szczecin at least 50 years earlier (leg. Moelendorf 1889; WitTe 1909: obs. in 1885). So far, it was found in 10 localities and noted most frequently in the Opole region (Michalak 1971, 1976, 1981). The published data about its localities are only of descriptive value and do not consider long-term perspectives of population stability. None of former localities was subsequently visited. Also, there was no attempt 
made to monitor the possibility of the species spread to semi-natural habitats, as indicated by TRZCIŃSKATACIK (1967). In this situation, it is difficult to determine the status of the species naturalization in Poland. According to RostańsKI \& SowA (1986-1987) and MichalaK (1981), all populations of M. wolgica had an ephemeral status. However, TOKARSKA-GuZIK (2005) indicated that the species deserves the kenophyte status.

The one-year study of M. volgica population in the locality Gosławice is certainly not sufficient to draw conclusions about the dynamics and stability of this population. However, when taking into account the considerable size of this population, consisting of about 500 flowering, fruiting and seeding individuals, $M$. wolgica can be considered a relatively stable element of the ruderal flora of post-mining habitats in Konin region.

A common practice used in agricultural reclamation of post-mining areas is sowing of pioneer plants that are resistant to adverse habitat conditions and activate biologically dead substratum. This group of plants includes some species of the family Fabaceae (Skawina 1963, Mocek-PŁóciniak 2014). Although, there are no data on using $M$. wolgica in land reclamation procedures, an accidental spread of its diasporas brought with the diasporas of $M$. alba cannot be excluded. BALCERKIEWICZ \& PAWLAK (1990) reported that M. alba was sown on the slopes and escarpments of Konin coal basin for stabilization purposes.

The spread of $M$. wolgica in the studied post-mining area may be encouraged by the abundance of nitrogen-poor clayish and sandy formations, unfavorable for the spread of other species.

\section{CONCLUSIONS}

Melilotus wolgica originates from the steppe areas of eastern Ukraine, south-west Russia and western Kazakhstan. It spreads mainly in the north-west direction, through overland routes and sea transportation. The species was brought into the port towns of West and North Europe together with cereals as early as in the $19^{\text {th }}$ century. In East Europe, apart from natural habitats, it occupies anthropogenic habitats along transportation routes.

In Poland, M. wolgica has been observed in 10 localities thus far (mainly in the Opole region). A large population of this species discovered in the locality near Gosławice in 2012 is the first one reported from Wielkopolska. It occupies an area of $290 \mathrm{~m}^{2}$ in the eastern part of a coal ash storage reservoir of the Konin Power Plant. The species is a component of the ruderal community Melilotetum albo-officinalis. An abundant flowering, fruiting and seeding make it possible to recognize it as a relatively stable element of the flora of Wielkopolska.
Presumably, M. wolgica was brought into this area together with the seeds of $M$. alba, which were used for the stabilization of slopes and escarpments in the Konin coal basin.

\section{AKNOWLEDGEMENTS}

I warmly thank Prof. Karol Latowski from the Adam Mickiewicz University in Poznań and Dr Maksim Dzhus from the Belarus State University in Minsk for their kind help in the verification of localities from the area of Ukraine and Belarus.

\section{REFERENCES}

Abdurzakova N.I., Taysumov M.A., Magomadova R.S., Astamirova M.A., Khasujeva B.A., Kushalieva J.A., IsRAILova S.A. (2013): Analiz rastitiel'nosti polupustyn' teritorii Tersko-Kumskoy Nizmennosti w raznykh ekologicheskikh uslovyakh. Rasteniyevodstvo. Vestnik KrasGAU 6: 87-92.

Agafonov V.A. (2004): Galofil'naya flora srednego Dona. Vestnik WGU. Serija: Khimiya, Biologiya, Farmatsiya 2: 79-89.

ARonsson M. (1994): Floristiska notiser från Sörmland och Uppland. Daphne 5(2): 62-67.

Balcerkiewicz S., Pawlak G. 1990. Zbiorowiska roślinne zwałowiska zewnętrznego Pątnów-Jóźwin w Konińskim Zagłębiu Węgla Brunatnego. Badania Fizjograficzne nad Polską Zachodnią 40: 57-106.

Baranova O.G., Puzyrev A.N. (2012): Konspekt flory Udmurtskoy Respubliki (sosudistyye rasteniya): Monografiya. Institut Komp'uternykh Issledovaniy, Moskva-Izhevsk. 212 pp.

Bespalov S., phot., 08.06.2013. http://www.plantarium.ru/page/image/id/207553.html

BJøRNDALEN J.E. (1971): Bidrag til karplantefloraen ved Langesundsfjorden. I. Blyttia. Norsk Botanisk Forenings Tidsskrift 29 (4): 257-267.

BoвRov E.G. (1939): Dikorastushchyye donniki SSSR (sistematicheskiy obzor). Soviet Botanist. 1939, 1: 41-53.

Bobrov E.G. (1945): Rod Melilotus. In: V.K. Schischkin, E.G. Bobrov (eds). Flora SSSR. Vol. 11 Izdatelstvo Akademii Nauk SSSR. Moskva-Leningrad: 183, 189.

BorIsova E.A. (2006): Novye i redkiye adventivnyye vidy Ivanovskoy, Vladimirskoy i Kostromskoy Oblastey. Bulletin MOIP (Biology) 111, 6: 63-66.

Bragina T.M., Bragin E.A., Tairbergenov Y. (2007): Naurzum State Nature Reserve. In: Nomination Dossier Saryarka - Steppe and Lakes of Northern Kazakhstan - For inscription on the list of cultural and natural world heritage of UNESCO. Provided by the Government of the Republic of Kazakhstan. 
Buttlen K.P., Harms K.H. (1998): Florenliste von Baden-Württemberg. Liste der Farn- und Samenpflanzen (Pteridophyta et Spermatophyta). Landensanstalt für Umweltschutz, Baden-Württembrg.

ĆwIKLIŃsKi E. (1970): Flora synantropijna Szczecina. Monographiae Botanicae 33: 1-103.

DANCHENKO N.V. (2010): Zhyttyevi formy ta tsenotychni osoblyvosti dykoroslykh predstavnykiv rodyny bobovykh (Fabaceae), poshyrenykh v Kyyivskiy oblasti. In: E.L. Kordyum, O.V. Burova, V.M Gerasimchuk, L.V. Dimitrova, I.A. Korotchenko, A.S. Mossyakin, M.M. Peregrim, O.M. Peregrim, O.V. Polischuk (eds). Aktual'ni problemy botaniky ta ekolohiyi. Materialy mizhnarodnoyi konferentsiyi molodykh uchenykh, Instytut Botaniki im. M.H. Kholodnoho NAN Ukrayiny. 22-25.09.2010, Yalta: 196-198.

DAvYDov D.A., phot., 27.07.2011. http://www.plantarium.ru/page/image/id/121334.html

Duвoviк D.V. (2006): Features naturalization adventitious and cultivated species of vascular plants in the eastern part of Belarus. Young researchers botanical science 2006, 21-22 September 2006. Ministry of Education RB, RO, Gomel State University. Skaryna, Proceedings of the International Scientific and Practical. Confenrence. In: N.M. Dayneko (ed.). Gomel Fr. Skaryna State University, Gomel: 11-15. MSK.

Dzyubenko N.I., Dzyubenko E.A. (2004): 2003-2009 Project "Interactive Agricultural Ecological Atlas of Russia and Neighboring Countries. Economic Plants and their Diseases, Pests and Weeds". http://www.agroatlas.ru/en/autors (access: 14. 12.2014).

Fedorova L.V. (2015): Adventivnaya flora goroda Orekhowo-Zuyevo i orekhovo-zuyevskogo rayona v gerbarii Moskovskogo Gosudarstvennogo Oblastnogo Gumanitarnogo Instituta. Penzevskiy Gosudarstvennyy Institut, Penza: 97-102.

Gafurova M.M. (2014): Sosudistyye rasteniya Chuvashskoy Respubliki. Flora Volzhskogo basseyna. Vol. 3. Kassandra, Togliatti.

Galovina G.B., TABAKa L.V. (1985): Flora goroda Daugavpils. In: L.V. Tabaka (ed.). Flora i rastitelnost' Latviyskoy SSR. Vostochno-Latviyskiy geobotanicheskiy rayon Zinatne. Zinatne, Riga: 184-269.

Gams H. (1924): Leguminosae. In: G. Hegi (ed.) Illustrierte Flora von Mitteleuropa, B and 4.3. Lechmanns Verlag, München: 1238, 1239, 1247-1248.

Gojdičová E., Cvachová A., Karasová E. (2002): Zoznam nepôvodných, inváznych a expanzívnych cievnatých rastlín Slovenska. 2. Ochrana Prírody 21. Banská Bystrica: 59-79.

Golyusheva A.N., Rakov N.S., Senator S.A. (2011): Flora PGT Cherdakly (Ul'yanovskoye Zavolzhye).
Samarskaya Luka: problemy regional'noy i global'noy ekologii 20(1): 49-103.

Greuter W., Raus Th. (eds) (2010): Med-Checklist Notulae, 29. Willdenowia 40: 189-204.

HANSEN A. (1968): Melilotus Miller. In: T.G. Tutin, V.H. Heywood, N.A. Burges, D.M. Moore, D.H. Valentine, S.M. Walters, D.A. Webb (eds). Flora Europaea 2: 148-150.

Heukels H. (1927): Nieuwe vindplaatsen in Nederland van Zeldzame Plantensoorten in 1926. De Levende Natuur 31(12): 378-380.

Holzfuss E. (1937): Beitrag zur Adventivflora von Pommern. Dohrniana 16: 94-130.

Homlya L.M., Davydov D.A. (2006): Dopovnennya do "Konspektu flory livoberezhnoho Prydniprov'ya" Poltavs'koho Rayonu Poltavs'koy oblast. Naukovyy chasopys NPU im. M.P Drahomanova. Ser. 20, Biolohiya 2: 3-11.

Höck F. (1910): Neue Ankkömmlinge in der Pflanzenwelt Mitteleuropas. Beihefte Botanischen Centralblatt 26: 391-433.

ILINA V.N. (2013): Flora domashkinykh verschin (Kinel'sky i Neftegorsky rayony Samarskoy oblasti). Fitoraznoobraziye vostochnoy Yevropy 7(2): 4149.

Jehlík V., Dostálek J. (2008): Influence of railway transport in the South-East of Slovakia on formation of adventive flora in Central Europe. Biodiversity: Research Conservation 11-12: 27-32.

KARLEN L. (1996): Adventivexkursionen 1996. Daphne 7(2): 75-76.

KASIŃSKI J.R. (2005): Elektrownie składują odpady w wyrobiskach węgla brunatnego. Informator Centrum Doskonałości Badań Środowiska Abiotycznego 11: 4-7.

Kloos A.W., Wachter W.H. (1933): Nieuwe vindplaatsen in Nederland van Zeldzame Plantensoorten in 1932. De Levende Natuur 37(12): 385-388.

Kolchanov R.A, Kolchanow A.F., Ngo Thy Siem Kieu (2012): Semeystwo bobovyye (Fabaceae) vo flore Belgorodskoy oblasti. Nauchnyye vedomosti Belgorodskogo gosudarstvennogo universiteta. Seriya: Yestestvennyye nauki 3(122), 18: 36-49.

Kondratyuk E.N., Burda R.I., Chuprina T.T., KhoMYAKOV M.T. (1988): Luganskiy gosudarstvennyy zapovednik. Rastitiel'nyy mir. Naukova Dumka, Kiev.

Koopman J., Jacobs I., Verloove F. (2014): Carex melanostachya (Cyperaceae), standhoudend in Antwerpen-Linkeroever (België). Dumortiera 105: 3-8.

Kostrakiewicz K. (1959): Papilionaceae. In: W. Szafer, B. Pawłowski (eds). Flora polska 8. Państwowe Wydawnictwo Naukowe, Kraków: 7-184.

KRYTSKA L.I. (1987): Fabaceae. In: Yu.N. Prokudin (ed.). Opredelitel vyssshikh rasteniy Ukrainy. Naukova Dumka, Kiev. 
KRYTSKA L.I. (2014): Konspekt rodu Melilotus (Fabaceae) flory Ukrainy. Ukrainian Botanical Journal 71(1): 36-40.

Kulikov P.V. (2005): Konspekt flory Chelyabinskoy oblasti (sosudistyye rasteniya). Ural'skoye Otdeleniye Rossiyskoy Akademii Nauk, Botanicheskiy Sad. Il'menskiy Gosudarstvennyy Zapovednik, Yekaterinburg.

Kuzovenko O.A., Plaksina T.I. (2010): Urochishche Gryzly - unikal'nyy stepnoy pamyatnik prirody samarskoy oblasti. Vestnik SamGU - Yestestvennonauchnaya seriya 2(76): 178-202.

LAIVIN̦Š M., GAVRILOVA G. (2009): Biogeographical analysis of vascular plant flora in Ventspils and Daugavpils cities. Latvijas veǵetācija 18: 25-64.

LAKTIONOV A.P. (2010): Flora Astrakhanskoy oblasti. Monografija. Izdatel'skiy dom "Astrakhanskiy universitet", Astrakhan.

LID J. (1952): Norsk flora. Det Norske Samlaget, Oslo.

LID J. (1963): Norsk og svensk flora. Det Norske Samlaget, Oslo.

Lomonosova M.N., SukHorukov A.P. (2000): Floristicheskoye nakhodki w Yuzhnoy Sibirii. Turczaninowia 3(4): 64-66.

Losev G.A., Jans L., Pilipenko V.N., Lukaikin V.A. (1998): Flora of the Volga Delta. A check list of the vascular plants of the Volga Delta, Russia. Lelystad/Astrakhan.

Malysheva V.G. (1979): K adventivnoy flore Kalininskoy oblasti. Ekologiya rasteniy yuzhnoy taygi. Izd. KGU, Kalinin: 48-53.

Matuszkiewicz W. (2001): Przewodnik do oznaczania zbiorowisk roślinnych Polski. In: J.B. Faliński (ed.). Vademecum Geobotanicum 3. Wydawnictwo Naukowe PWN, Warszawa.

MAYEVSKIY P.F. (1964. Flora sudney polosy yevropeyskoy chasti SSSR. Izd. "Kolos", Moskva.

Medvecká J., Kliment J., Májeková J., Halada L., ZALiberová M., Gojdičová E., Feráková V., JarolímeK J. (2012): Inventory of the alien flora of Slovakia. Preslia 84: 257-309.

MichalaK S. (1971): Interesujące gatunki synantropijne $z$ terenu miasta Opola. Cz. 2. Fragmenta Floristica et Geobotanica 17(1): 11-16.

MichalaK S. (1976): Nowe stanowiska rzadszych roślin synantropijnych w woj. opolskim. Zeszyty Przyrodnicze OTPN 16: 33-49.

MichalaK S. (1981): Lista efemerofitów Opolszczyzny. Zeszyty Przyrodnicze OTPN 20: 15-29.

Mininzon I.L. (2015): Flora Nizhnego Novgoroda. Devataya elektronnaya versiya, www.dront.ru/ files/publications/2015/Flora_NN_IX.doc (access: 19.03.2015).

Mirek Z., PięKoś-Mirkowa H., Zając A., ZajĄC M. (2002): Flowering plants and pteridophytes of Poland. A checklist. Krytyczna lista roślin naczynio- wych Polski. W. Szafer Institute of Botany, Polish Academy of Sciences, Kraków.

MoceK-PŁóciniaK A. (2014): Biologiczna rekultywacja terenów zdegradowanych po eksploatacji węgla brunatnego i rud miedzi. Nauka Przyroda Technologie 8, 3, \#42.

Muldasheva E.M. (2012): Konspekt flory goroda Engel'sa. GOU VPO Saratovsky Gosudarstvennyy Universitet im. N.G. Chernyshevskogo, Saratov: $1-29$.

Naumenko N.I. (2010): Flora rechnykh dolin Zauralskoy lesostepi. Sravnitelnaya floristika. Chast' 2. Trudy Ryazanskogo Otdeleniya Russkogo Botanicheskogo Obshchyestva 2: 42-50.

Naumenko N.I., Vaseyeva M.A., Mochalov A.S. (2011): Materialy Krasnoy Knigi Kurganskoy oblasti: rosteniya nuzhdayushchiyesya $\mathrm{V}$ regional'noy okhrane. Seriya "Yestestvennyye nauki". Vestnik KGU 2(21), vyp. 4: 59-72.

NAUMENKO N.I. (2012): Sistematicheskiy spisok pokrytosemennykh rasteniy, vnesonnykh v Krasnuyu knigu. Krasnaya kniga Kurganskoy oblasti. Chast' 2. Rasteniya. Griby. Lishayniki Kurganskoy oblasti, s ukazaniyem kategorii statusa okhrany. Kurgansky Gosudarstvennyy Universitet, Kurgan 186-448.

Nevskiy M.L. (1947-1952): Flora Kalininskoy oblasti: Opredelitel' pokrytosemennykh (tsvetkowykh) rasteniy dikoy flory. Uchen. Ch. 2: [Leguminosae - Najadaceae]. 1952. Zapiski Kalininskogo Pedagogicheskogo Instituta 11, 2: 309-1033.

NioRdson N. (2000): Floran på våra soptippar i Blekinge. Blekinges Natur 2000: 108-119.

Notov A.A. (2009): Adventivnyy komponent flory Tverskoy oblasti. Dinamika sostava i struktury. Federalnoye agenstvo po obrazovaniyu. Gosudarstvennoye obrazovatelnoye uchrezhdeniye vysshego professional'nogo obrazovaniya. Tverskoy Gosudarstvennyy Universitet, Tver.

Notov A.A., Pavlov A.V., Notov V.A. (2009): Adventivnaya flora Natsionalnogo Parka "Zavidovo". Vestnik TvGU. Seriya "Biologiya i ekologiya" 12: 153-172.

OpMANIS A. phot., 27.06.2011, http://dziedava.lv/ daba/izveletadaba.php

Oprea A. (2005): Lista critică a plantelor vasculare din România. Editura Universității "Al.I. Cuza", Iaşi.

Ostapko V.M., Boyko A.V., Mulenkova E.G. (2009): Adventivnaya fraktsiya flory yugo-vostoka Ukrainy. Promyshlennaya Botanika 9: 32-47.

Ostenfeld C.H. (1909): Smaa Bidrag til den danske Flora V. Botanisk Tidsskrift, Dansk Botanisk Forening 29: 326-330.

ÖRnEBERG B. (2010): Malmös flora - en översiktlig beskrivning, 1-10 pp., http://malmo.se

Paczoski J. (2008): (ed. K. Latowski). Khersonskaya flora. Vol. 2. Dvudolnye. Uniwersytet im. Adama 
Mickiewicza w Poznaniu, Zakład Taksonomii Roślin, Poznań: 505.

PARfENOv V.I. (1999): Opredelitel' vysshikh rasteniy Belarusi. Dizayn PRO, Minsk.

PAWŁowsKI B. (1977): Skład i budowa zbiorowisk roślinnych oraz metody ich badania. In: W. Szafer, K. Zarzycki (eds). Szata roślinna Polski. T. 1. PWN, Warszawa: 237-269.

Poppendieck H-H., Bertram H., Brandt B., Kreft K.A., Kurz H., Onnasch A., Preisinger H., Ringenberg J., Prondzinski J., Wiedemann D. (2010): Rote Liste und Florenliste der Gefäßpflanzen von Hamburg. Frei und Hansestadt Hamburg Behörde für Stadtentwicklung und Umwelt Abteilung Naturschutz, 54 pp., www.hamburg.de/start-natur (access: 5.12 .2014$)$.

Prasse R., Ristow M., Klemm G., Machatzi B., Raus T., Scholz H., Stohr G., Sukopp H., Zimmermann F. (2001): Liste der wildwachsenden Gefäßpflanzen des Landes Berlin mit Roter Liste. Senatsverwaltung für Stadtentwicklung/Der Landesbeauftragte für Naturschutz und Landschaftspflege, Kulturbuch-Verlag, Berlin.

Puzyrev A.N. (2006): O nakhhodkakh adventivnykh vidov rasteniy na shosseynykh dorogakh Udmurtii. Vestnik Udmurtskogo Universiteta. Biologiya 10: 25-36.

PyšEK P., SÁdlo J., MANDÁK B. (2002): Catalogue of alien plants of the Czech Republic. Preslia 74: 97-186.

Rakov N.S., Saksonov S.V., Senator S.A., Vasyukov V.M., Ivanova A.V., Safronova I.N., Gorlov S.E. (2013): Desyataya ekspeditsija Instituta Ekologii Volzshskogo Basseyna RAN: flora Sengileyevskikh Gor (Ul'janovskoye Predvolzhye). Fitoraznoobraziye vostochnoy Yevropy 7(1): 79-103.

Rakov N.S., Saksonov S.V., Senator S.A., Vasyukov V.M. (2014): Sosudistyye rasteniya Ulyanovskoy oblasti. Flora Volzhskogo basseyna. Vol. 2. Kassandra, Togliatti.

RostAŃSKi K., SowA R. (1986-1987): Alphabetical list of the ephemerophytes of Poland. Fragmenta Floristica et Geobotanica 31-32(1-2): 151-205.

Rozumova E.V., Agafonov V.A. (2012): O nekatorykh adventivnykh i redkikh vidakh flory transportnykh magistraley Voronezhskoy oblasti. In: A.V. Poluyanov (ed.). Flora i rastitel'nost' Tsentral'nogo Chernozem'ya. Materialy nauchnoy konferentsi, Kurskiy Gosudarstvennyy Universitet. Tsentral'no-Chernozemny zapovednik 6: 86-89.

Schulz O.E. (1901): Monographie der Gattung Melilotus. Botanische Jahrbücher für Systematik, Pflanzengeschichte und Pflanzengeographie 29(5): 660-735.

Schulz O.E. (1910): Floristiche Beobachtungen im Kreise Zauch-Berlin. Verhandlungen des Botanischen Vereins der Provinz Brandenburg. Im Auf- trage des Vereins herausgegeben von den Schriftführen. Selbstverlag des Vereins, Berlin: 51-54.

Saksonov S.V., Rakov N.S., Vasyukov V.M., Ivanova A.V., Savenko O.V., Senator S.A. (2007): Ekspeditsija-konferentsija posvyaschennaya pamyati professora V.V. Blagoveschenskogo, 25.06-7.07. 2007 g. Fitoraznoobraziye Vostochnoy Yevropy 3: 207-214.

SENATOR S.A. (2008): Flora Volgo-Irgizskogo Landshaftnogo Rayona (Samarsko-Saratovskoye nizmennoye Zavolzh'ye). Fitoraznoobraziye Vostochnoy Yevropy 8: 96-185.

SEREgin A.P. (2012): Flora Vladimirskoy oblasti. Konspekt i atlas. ASTRA, Tula.

Sharonova I.V., Plaksina T.I. (2006): Flora uchastka "Talovskaya step" Gosudarstvennogo zapovednika "Orenburgskiy". Fitoraznoobraziye Vostochnoj Yevropy 1: 30-46.

Sidorova T.V. (2006): Korgalzhynsky gosudarstvennyy prirodnyy zapovednik. In: R.V. Yaschenko (ed.). Zapovedniki Sredney Azii i Kazakhstana. Materialy proyekta MSOP. Otsenka effektivnosti upravleniya zapovednikami Sredney Azii i Kazakhstana. Seriya "Okhranyayemyye prirodnyye territorii Sredney Azii i Kazakhstana”, IUCN The World Conservation Union, Almaty: 48-71.

Sidorova T.V. (2007): Korgalzhyn State Nature Reserve. In: Nomination Dossier Saryarka - Steppe and Lakes of Northern Kazakhstan - For inscription on the list of cultural and natural world heritage of UNESCO. Provided by the Government of the Republic of Kazakhstan.

SKAwINA T. (1963): Rekultywacja terenów poeksploatacyjnych górnictwa odkrywkowego węgla brunatnego. Węgiel Brunatny 3: 151-242.

Slavík B. (ed.) (1995): Květena České republiky. Vol. 4. Academia, Praha.

Stankov S.S., Taliyev V.I. (1949): Opredelitel vysshikh rasteniy yevropeyskoy chasti SSSR. Gos. Izd. "Sovetskaya Nauka", Moskva.

Ştefănuț S., Sanda V., Öllerer K., Vicoi I., Ion R. (2009): Atlas Florae Romaniae. Vol. 6. Fabaceae: Medicago, Melilotus, Ononis ş Trigonella. Ars Docendi Universitatea din București.

SuDNIK-Wójcikowska B. (1987): Flora miasta Warszawy i jej przemiany w ciągu XIX i XX wieku. Część 1 i 2. Wyd. Uniwersytetu Warszawskiego, Warszawa.

Sukhorukov A.P., VAsyukov V.M., Rakov N.S., LySENKo T.M. (2013): Dopolneniye k flore Samarskoy oblasti. Fitoraznoobraziye Vostochnoy Yevropy 7(4): 77-92.

SylvÉN N. (1931): Bidrag till Skånes flora. 2. Nya fyndlokaler för adventivarter inom Skånefloran. Botaniska Notiser, Lund: 207-212.

Svensson A., Edelsjö J., Ekman J., Gudmundsson H., ODElvik G. (2001): Floran på tippar i Uppland och Södermanland 1990-1999. Daphne 12(2): 1-157. 
Szotкоwski P. (1988): Flora synantropijna portów rzecznych Górnej Odry. Gliwice, Koźle, Opole. Muzeum Śląska Opolskiego, Opole.

Talovina G.V. (2011): Rod Melilotus Mill. vo flore Rossii i sopredel'nykh stran (sistematika geografiya, ekologiya, strategiya sokhraneniya). Botanika. Avtoreferat dissertatsii na soiskaniye uchenoj stepeni kandidata biologicheskikh nauk. Sankt-Peterburg, www.vir.nw.ru (access: 06.12.2014),

Talovina G.V., SmeKalova T.N. (2005): Vidy roda Melilotus Mill. na teritorii Sibirii. Problemy botaniki Yuzhnoy Sibirii i Mongolii. In: Materialy IV Mezhdunarodnoy nauchno-prakticheskoy konferentsi. 12-14.12.2005, Barnaul: 82-86.

TAlTs S. (1959): Papilionaceae. Eesti NSV Floora. Vol. 3. Eesti Riiklik Kirjastus, Tallin: 76, 77, 504.

TAYsumov M.A. (2013): Floristicheskiye i faunisticheskiye resursy Chechenskoy Respubliki. Vestnik Akademii Nauk Chechenskoy Respubliki 1(18): 44-55.

ToKARSKA-GuZIK B. (2005): The establishment and spread of alien plant species (Kenophytes) in the flora of Poland. Wyd. Uniwersytetu Śląskiego, Katowice.

TøMMERÅS B.Å. (ed.) (1994): Introduksjoner ov fremmede organismer til Norge. Norsk Institutt for Naturforskning 62: 1-141.

TrZcińsKa-TaciK H. (1967): Melilotus indicus (L.) All. i M. volgicus Poir. w Polsce. Fragmenta Floristica et Goobotanica 13(3): 351-355.

Verloove F. (2006): Catalogue of neophytes in Belgium (1800-2005). In: E. Robbrecht (ed.). Miscellaneous documentation published by the $\mathrm{Na}-$ tional Botanic Garden (Belgium). Scripta Botanica Belgica 39: 1-89.

Weimarck H. (1963): Skånes Flora. Bokförlaget Corona, Lund.

WiLling R., WiLling E. (2003): A Willing contribution to flora Hellenica. Field records 2002. Published by BGBM Press Botanic Garden and Botanical Museum Berlin-Dahlem, Dessau.

Witte H. (1909): Några bidrag till Kännedomen om vegetationen på våra ruderatplatser. In: $\mathrm{O}$. Rosenberg, T. Vestergren (eds). Svensk Botanisk Tidskrift. Svenska Botaniska Föreningen 3(2): 174-182.

YANCHURKINA A.A. (1976): Floristicheskiy sostav i rasprostraneniye sornykh rasteniy Kuybyshevskoy oblasti. Manuscript. Leningrad.

Yena A.V. (2012): Prirodnaya flora Krymskogo poluostrowa. N. Orianda, Simferopol.

ZAJĄC A. (1978): Założenia metodyczne „Atlasu rozmieszczenia roślin naczyniowych w Polsce". Wiadomości Botaniczne 22(3): 145-155.

Zając A., Zając M. (eds) (2001): Atlas rozmieszczenia roślin naczyniowych w Polsce. Pracownia
Chorologii Komputerowej Instytutu Botaniki UJ, Kraków.

For citation: Chmiel J., Mielczarek S. (2016): Melilotus wolgica Poir. in Lam. (Fabaceae) in Eurasia: distribution and habitats. Steciana 20(3): 159172. doi: $10.12657 /$ steciana.020.017

\section{APPENDIX 1}

\section{COMPILATION OF DATA ON THE OCCURRENCE OF MELILOTUS WOLGICA IN EURASIA}

\section{KAZAKHSTAN}

1. Korgalzhyn state nature reserve, Akmola Region (SIDOROVA 2006, 2007)

2. W part of Kokshetau District, Akmola Region, clayish escarpments of river banks, valleys of steppe rivers (Talovina \& SmeKalova 2005, after BOBRov 1945)

3. Atbasar District, Akmola Region, clayish escarpments of river banks, valleys of steppe rivers (TAlovina \& SMeKalova 2005, after Bobrov 1945)

4. N part of Kostanay Region, right bank of the Tobol river (NAUMENKo 2012)

5. Naursum state nature reserve, Kostanay Region (Bragina et al. 2007)

6. Uralsk, West Kazakhstan Region (Schulz 1901).

\section{RUSSIA}

7. Arkhangelsk (Schulz 1901, Bobrov 1945)

8. Kuznetsk, Penza Oblast (Bobrov 1945)

9. Khvalynsk, Saratov Oblast (BoBrov 1945)

10. Kama, Tatarstan (Bobrov 1945)

11. Sarepta, Volgograd Oblast (Schulz 1901) (former Stalingrad Oblast), generally reported from the region (MaYevskiy 1964, TAliyeva 1949)

12. Mikhaylovka near Medvedica river, Volgograd Oblast (Schulz 1901)

13. Rostov (Schulz 1901), generally reported from the region (STANKov \& TALIYEv 1949)

14. Rostov reserve, Rostov Oblast (TALOvina 2011)

15. Tundutovo, Kalmykiya Republik (Schulz 1901)

16 . Voronezh, recognized as a kenophyte or ephemerophyte (MAYEWSKIY 1964)

17. Podgorensky, Bogucharsky, Nowokhopyorsky, Povorinsky District, Voronezh Oblast (AGAFONOV 2004)

18. Khopyorsky reserve, Borisoglebsk District, Voronezh Oblast (TaLovina 2011)

19. Borisoglebsk, Voronezh Oblast, by the town's exit road towards west (Rozumova \& Agafonov 2012, obs. Rozumova, 10.08.2010) 
20. Galischya Gora reserve, Zadonsky District, Lipetsk Oblast (TALOVINA 2011)

21. Tver, Doroshikha railway station (NevskIY 19471952, leg. A.A. Notov, 11.09.2004, TVBG)

22. Savelovo, Sonkovsky District, Tver Oblast, observed at the railway station in the second half of the 1970s (Notov 2009, after Malysheva 1979)

23. Rzhev, Rzhevsky District, Tver Oblast, observed at the railway station in the second half of the 1970s (Notov 2009, after Malysheva 1979, obs. 18.07.1978)

24. Kuvshinovo, Kuvshinovsky District, Tver Oblast, observed at the railway station in the second half of the 1970s (Notov 2009, after MaLysheva 1979)

25. Bologoye, Bologovsky District, Tver Oblast, observed at the railway station in the second half of the 1970s (Notov 2009, after Malysheva 1979)

26. Nelidovo, Nelidovsky District, Tver Oblast, observed at the railway station in the second half of the 1970s (Notov 2009, after Malysheva 1979)

27. Toropets, Toropetsky District, Tver Oblast, observed at the railway station in the second half of the 1970s (Notov 2009, after Malysheva 1979)

28. Sandovo, Sandovsky District, Tver Oblast, observed at the railway station in the second half of the 1970s (Notov 2009, after Malysheva 1979, obs. 20.08.1979)

29. Redkino, Konakovsky District, Tver Oblast, observed at the railway station in 1985, herb. TVBG (Notov 2009, Notov et al. 2009)

30. Zavidovo, Konakovsky District, Tver Oblast, observed at the railway station in 1990 (Notov et al. 2009)

31. All regions except Baskunkhakskogo and Bogdinskogo, Astrakhan Oblast, quite rarely, disturbed fragments of vegetation (LAKTIONOv 2010), generally reported from the region (STANKOV \& TALIYEV 1949)

32. Middle part of the Volga delta, Astrakhan Oblast (Losev et al. 1998)

33. Kovrov, Kovrovsky District, Vladimir Oblast, gravel ground at the railway station (Borisova 2006, obs. Borisova 2005)

34. Railway line Murom-Kovrov, Vladimir Oblast, sandy and gravel embankments and road shoulders (SEREgin 2012, obs. Seregin 2009)

35. Murom, Muromsky District, Vladimir Oblast, sandy road shoulders R-72 (SEREGIN 2012, obs. Seregin 2009)

36. Ukrainka, Bolshechernigovsky District, Samara Oblast, Rostashi river valley, Artemisia-grass steppe (SuKHoRukov et al. 2013, obs. 19.08.2013)

37. Nature sanctuary of "Hole Gryzli" near the village of Koshkin, Bolshechernigovsky District, Samara Oblast (Kuzovenko \& Plaksina 2010)

38. Yuzhnosamarsky, Bezenchuksky District, Samara Oblast (SenATor 2008)
39. Yekaterinovka, Bezenchuksky District, Samara Oblast (SEnATor 2008)

40. Neftogorsky District, Samara Oblast, "Domashkiny Vershiny" steppes near river Domashka (ILINA 2013, obs. 1985)

41. Syrtovoye Zawolzhe, Bolshechernigovsky District, Samara Oblast, Artemisia-grass steppe (SuKHORUKOv et al. 2013, obs. 2013)

42. Engels, Engelssky District, Saratov Oblast, roadside of the forest track, recognized as a kenophyte or ephemerophyte (Muldasheva 2012)

43. Saratov Oblast, generally reported from natural localities (MAYEVSKIY 1964)

44. Saratov, abandoned sand excavation site at the town outskirts (photograph by BESPALOV 08.06.2013, http://www.plantarium.ru/page/image/id/207553.html)

45. Nizhny Novgorod (Kanavinsky, Moskovsky, Sovetsky, Prioksky District), wastelands and grasslands within the urban areas (Mininzon 2015)

46. Dimitrovgrad, Ulyanovsk Oblast (RAKOv et al. 2014, obs. Rakov, 22.06.2010, PVB)

47. Maynsky, Melekessky, Radishchevsky District, Ulyanovsk Oblast (RaKov et al. 2014)

48. Ulyanovsk (Bobrov 1945, Rakov et al. 2014), generally reported from the region (MAYEVSKIY 1964)

49. Cherdakly, Cherdaklinsky District, Ulyanovsk Oblast, railway grounds, anthropophyte (GALYUSHEVA et al. 2011, RaKov et al. 2014)

50. Sengileyevskye gory, Sengileyevsky District, Ulyanovsk Oblast, shores of the Kuybyshev Reservoir (RAKOv et al. 2013)

51. Ust' Kulatka, Starokulatkinsky District, Ulyanovsk Oblast, Kulatka river, obs. 27.06.2007 (SAKSONOv et al. 2007)

52. Russkaya Bektyashka, Sengilevsky District, Ulyanovsk Oblast, Volga river, Kuray nature reserve, obs. 05.07.2007 (SAKSONOv et al. 2007)

53. Izhevsky, Yarsky, Glazovsky, Balezinsky, Igrinsky District, Votkinsky, Zavyalovsky, Malopurginsky, Sarapulsky, Kambarsky, Udmurt Republic, railway track, rarely road shoulders, cereal and vegetable collecting centers (Baranova \& Puzyrev 2012)

54. Road Izhevsk-Sarapul, Zavyalovsky District, Udmurt Republic, road shoulder, obs. 22. 09.2002, in 2 places (0.5 and $2.5 \mathrm{~km}$ E of Kamennoye) (Puzyrev 2006, Baranova \& Puzyrev 2012)

55. Ust-Uyskoye, Tselinnoy District, border between Kurganskoy and Kustanayskoy oblastey, slopes with steppe and forest steppe on marl outcrops (NAumenKo 2010, 2011, KuLIKOv 2005)

56. Kuybyshev Oblast, generally reported from the region (Stankov, Taliyev 1949, Mayevskiy 1964, YANCHURKINA 1976) 
57. Nizhny Novgorod Oblast (former Gorki Oblast), generally reported from natural localities (MAYEVSKIY 1964)

58. Belgorod Oblast, generally reported from natural localities (MAYEVSKIY 1964)

59. Veydelevsky District, Belgorod Oblast, Popov rukav nature reserve (KolCHANOv et al. 2012)

60. Novosibirsk, brought into railway grounds (TALOvina \& SmeKalova 2005)

61. Barnaul, brought into railway grounds (TALOVINA \& SMeKalova 2005)

62. Berdsk, Novosibirsk Oblast, small population, 1 $\mathrm{km} \mathrm{N}$ of the Berdsk railway station (LOMONOSOvA \& SukHorukov 2000)

63. Tobolsk, Tyumen Oblast (Bobrov 1945)

64. Bolshaya Urtazymka River near Tselinnoje, Khaybullinsky District, Bashkiria (Kulikov 2005)

65. Orenburg (Schulz 1901)

66. Orenburg reserve, Pervomaysky District, Orenburg Oblast (Sharonova \& PLAKSINA 2006)

67. Kvarkeno, Kvarkensky District, Orenburg Oblast (Kulikov 2005)

68. Kulma, Kvarkensky District, Orenburg Oblast (Kulikov 2005)

69. Arkaim reserve, Bredy District, Chelyabinsk Oblast (Kulikov 2005)

70. Novinka, Chelyabinsk Oblast (Kulikov 2005)

71. Kulevchi, Vernensky District, Chelyabinsk Oblast (Kulikov 2005)

72. Oktyabrsky District, Chelyabinsk Oblast (KulIKOV 2005)

73. Terek-Kuma lowland, Stavropol Krai, generally reported from the region without locality information (AвDURzAKova et al. 2013)

74. Chechen Republic, generally reported from the area of Republic (TAYsumov 2013)

75. Moskva, generally reportes as a weed (MAYEVSKIY 1964)

76. Orekhowo-Zuyevo, Moskva Oblast, sandy areas along the Voksalnaya St. (Fedorova 2015)

77. Cheboksary, Chuvashia Republic, besides railway track - 2-5 km from the town towards Kanash (Gafurova 2014, obs. Dimitriev, 12.09.1981).

\section{AZERBAIJAN}

78. Ordubat (Schulz 1901, Bobrov 1945).

\section{UKRAINE}

79. Kherson (Bobrov 1945)

80. Oleksandrivka towards the town of Stanislav, Kherson Oblast, shores of the reservoir on the Boh river (PAczoski 2008, obs. date ?)

81. Between the towns of Shestirnya and Szyroke, Dnipropetrovsk Oblast, fields and roadsides (PAczoski 2008, obs. 1898/1988)
82. Volodymyrivka, Mykolaiv Oblast, roadside (PACZOSKI 2008, obs. 1898)

83. Bereznehuvate, Mykolaiv Oblast, roadside (PAczoski 2008, obs. date?)

84. Donetsk Oblast, noted sporadically or moderately often, not expansive (OsTAPKo et al. 2009)

85. Lugansk Oblast, noted sporadically or moderately often, not expansive (OstAPKo et al. 2009)

86. Lugansk Nature Reserve Park (Kondratyuk et al. 1988)

87. Kehychevka, Kharkiv Oblast, railway embankment near the bridge over the Vshyva river, (photography by D.A. DAVYDOV, 21.07.2011, http:// www.plantarium.ru/page/image/id/121334. html)

88. Gerivka near Poltava, near the road Klymivka-Lisok, sandy areas along the railway track, a new species for the flora of Poltava (HomLYA \& DAvYDOV 2006)

89. Kiev Oblast, generally reported from the region (DANCHENKo 2010)

90. Kharkov (KRYTSKA 1987)

91. Odessa (Schulz 1901, obs. since 1820)

92. Krym (YenA 2012).

\section{BELARUS}

93. Generally reported as an alien species, rarely occurring at the roadsides and railway grounds in the whole country (PARFEnov 1999)

94. Mozyr, Gomel Oblast, right bank of the Prypeć river, patch of $0.5 \times 1 \mathrm{~m}$ in area (leg. D.I. Tretyakov, 16.08.1980, MSK)

95. Svetlogorsk District, Gomel Oblast, right bank of the Berezyna river, sporadic occurrence (leg. M. Dzhus, 13.07.1998, MSKU)

96. Polotsk, Vitebsk Oblast, 1 specimen, yard near a glass wool factory (leg. G.V. Vynaev, D.I. Tretyakov, 18.07.1977, MSK)

97. Vitebsk, Vitebsk Oblast, $8 \mathrm{~km}$ from the railway station towards Polock (leg. G.V. Vynaev, 03.10.1979, MSK)

98. Pashino, Orsha District, Vitebsk Oblast, sand and gravel excavation sites (Dubovik 2006, leg. D.V. Dubovik, G.I. Tretyakov, 27.06.2002, MSK)

99. Dokšycy District, Vitebsk Oblast, $100 \mathrm{~m}$ from Krulevshchizna railway station towards Połock (leg. M. Dzhus, 27.07.1998, MSKU)

100. Leninsky District, Minsk, in the vicinity of railway track towards the Mill No. 5 (leg. E.E. Bludov, G.V. Vynaev, 04.07.1976, MSK)

101. Smolevichi District, Minsk Oblast, one specimen $3 \mathrm{~km}$ NE from the Zhodino railway station (leg. G.V. Vynaev, D.I. Tretyakov, 26.07.1976, MSK)

102. Koltsov Street, Minsk, between concrete flagstones (leg. D.I. Tretyakov, 1.08.1976, MSK) 
103. Minsk, near the railway track towards the Bakery No. 5 (leg. E.E. Bludov, 20.06.1977, MSK)

104. Minsk, at the crossing of Akademicka and Stoletova St., in the vicinity of Central Botanical Garden and a quarry edge, overgrowth of $3 \times$ $15 \mathrm{~m}$ in area (leg. G.V. Vynaev, D.I. Tretyakov, 30.06.1977, MSK)

105. Pukhovichi, Pukhovichi District, Minsk Oblast, about $8 \mathrm{~km} \mathrm{SE}$ from the railway station (leg. D.I. Tretyakov, G.V. Vynaev, 20.08.1977, MSK)

106. Minsk, near the railway station and highway (200 $\mathrm{m}$ from the Dolgobrodskaya St. overpass), $100 \mathrm{~m}$ towards Polock (leg. M. Dzhus, 27.08.1997, MSKU)

107. Brest, railway track (sand and gravel, an area of $2 \times 2 \mathrm{~m}) 3.5 \mathrm{~km}$ NNW from the railway station (leg. G.V. Vynaev, D.I. Tretyakov, 11.08.1977, MSK).

\section{LATVIA}

108. Daugavpils (Galovina \& TABAKA 1985, Laivinș̌ \& Gavrilova 2009)

109. Riga, vidzemes priekšpilsēta K̦ǐšezers (photograph by A. OpMAnIs, 27.06.2011, http://dziedava.lv/daba/izveleta_daba.php.

\section{ESTONIA}

110. Tallin (TALts 1959).

\section{ROMANIA}

111. Sfantu Gheorghe, Dobrogea Region, County of Tulcea, Danube Delta (Oprea 2005, ŞTeFănuț et al. 2009)

112. Sulina, Dobrogea Region, County of Tulcea, Danube Delta (Oprea 2005, ŞTEFĂNuȚ et al. 2009).

\section{GREECE}

113. Preweza, Nomos Preveza, Epirus Region, herbaceous vegetation between a road and Citrus orchard, obs. 2002, $18 \mathrm{~m}^{2}$ (GReuter \& Raus 2010)

114. Nikopolis, Nomos Preveza, Epirus Region (Greuter \& Raus 2010)

115. Parga, Nomos Preveza, Epirus Region (Greuter \& Raus 2010)

116. Stefani, Nomos Preveza, Epirus Region (GreuTER \& Raus 2010, Willing \& Willing 2003).

\section{SLOVAKIA}

117. Pannonian Region (SE Slovakia), ephemeral anthropophyte noted in 1968 (MEDVECKÁ et al. 2012)
118. Čierna n. Tisou, Trebišov District, Košice Region (Jehlík, Dostálek 2008).

\section{CZECH REPUBLIC}

119. Brno-Maloměřice, roadside, brought into the area (Slavík 1995, after leg. J. Dvorák 1971)

120. Dolní Řašnice, Liberec District, Liberec Region, roadside, brought into the area (SLAvík 1995, after leg. V. Jehlik 1963).

\section{GERMANY}

121. Berlin, Land Berlin (Witte 1909, Prasse et al. 2001)

122. Lehnin-Michelsdorf near Potsdam (Schulz 1910)

123. Baden-Württemberg (Buttler \& Harms 1998)

124. Bremen (WitTe 1909)

125. Kreuznach District (WITTE 1909)

126. München (WitTe 1909)

127. Hamburg (Witte 1909, Poppendieck et al. 2010)

128. Mannheim, port grounds (Höck 1910, noted in 1891, 1892 and 1898).

\section{NETHERLANDS}

129. Amsterdam (KLoos \& Wachter 1933, obs. 1932)

130. Weurt (Heukels 1927, obs. 1926).

\section{BELGIE}

131. Antwerp-Linkeroever, Flandria, obs. only in 1958 on the dry, sandy soil (Verloove 2006, alienplantsbelgium.be, Koopman et al. 2014).

\section{DENMARK}

132. Horsens (Ostenfeld 1909, obs. K. Wiinstadt 1906-1907)

133. Copenhagen, the suburb of Nørrebro, between Haraldsgade and Jagtvejen St. (Ostenfeld 1909, obs. J. Keiding 1907).

\section{SWEDEN}

134. Toftanäs-Malmö (Weimarck 1963, Örneberg 2010, S.E. Johansson, obs. 2000)

135. Nacka-Stockholm, near a mill, brought with cereals in 1890 (ARONSSON 1994, KarLeN 1996, Svensson et al. 2001)

136. Mörrum (NioRdson 2000)

137. Kristianstad (SYLVÉN 1931). 
NORWAY

138. Siloen, south Norway (BJøRNDALEN 1971, after LiD 1952, 1963)

139. Gjerpen (Skien), Telemark Region, south Norway (BJøRNDALEN 1971 after LID 1952, 1963)

140. Telemark, Hordaland, Trøndelag, Akershus Region, reported as an ephemerophyte (TøMMER̊̊s 1994).

\section{APPENDIX 2}

\section{COMPILATION OF DATA ON THE OCCURRENCE OF MELILOTUS WOLGICA IN POLAND}

\section{WEST POMERANIA VOIVODESHIP}

Generally reported from the Szczecin city area (leg. Moelendorf 1889, Witte 1909: obs. in 1885, HoLzFuss 1937).

1. Szczecin Golęcino, ATPOL AB73, by the Odra river (Gams 1924, after Kostrakiewicz 1959, HolzFuss 1937)

2. Szczecin, ATPOL AB73, between Niebuszewo and Grabowo, on the railway track (ĆWIKLIŃsKI 1970)

3. Szczecin, ATPOL AB83, ruble at Kolumb St. and on the Łasztownia island (ĆwiKLIŃsKi 1970).

\section{WIELKOPOLSKA VOIVODESHIP}

4. Gosławice near Konin, ATPOL CD17, embankments of a coal ash storage reservoir in the for- mer brown coal mine area "Gosławice" (leg. J. Chmiel, 12.06.2012, POZ).

\section{OPOLE VOIVODESHIP}

5. Opole, ATPOL CE95, railway tracks at the East Opole railway station (MichalaK 1971)

6. Zawadzkie, ATPOL CF09, railway station (МicHALAK 1976, obs. S. Michalak 1974)

7. Strzelce Opolskie, ATPOL CF18, railway station (Michalak 1976, obs. S. Michalak 1972)

8. Kędzierzyn-Koźle, ATPOL CF37, river port on the Odra river (MichaLAK 1981, SzotKowsKi 1988, obs. P. Szotkowski 1969)

9. Racibórz, ATPOL CF67, railway station (МiсHALAK 1976).

\section{MASOVIAN VOIVODESHIP}

10. Between Kawęczyn and Rembertów, ATPOL ED17, the east railway station (SUDNIK-WóJCIKOWSKA 1987).

\section{MAŁOPOLSKA VOIVODESHIP}

11. Cikowice n/Raba, ATPOL EF72, gravel-bank of the Raba river about $150 \mathrm{~m}$ from a railway track (TrzciŃsKa-TACIK 1967, obs. H. Trzcińska-Tacik and T. Tacik 1966).

\section{PODKARPACKIE VOIVODESHIP}

12. Medyka Rozrządowa, ATPOL GF81, reloading railway station (TRZCIŃSKA-TACIK 1967, obs. H. Trzcińska-Tacik and T. Tacik 1964). 